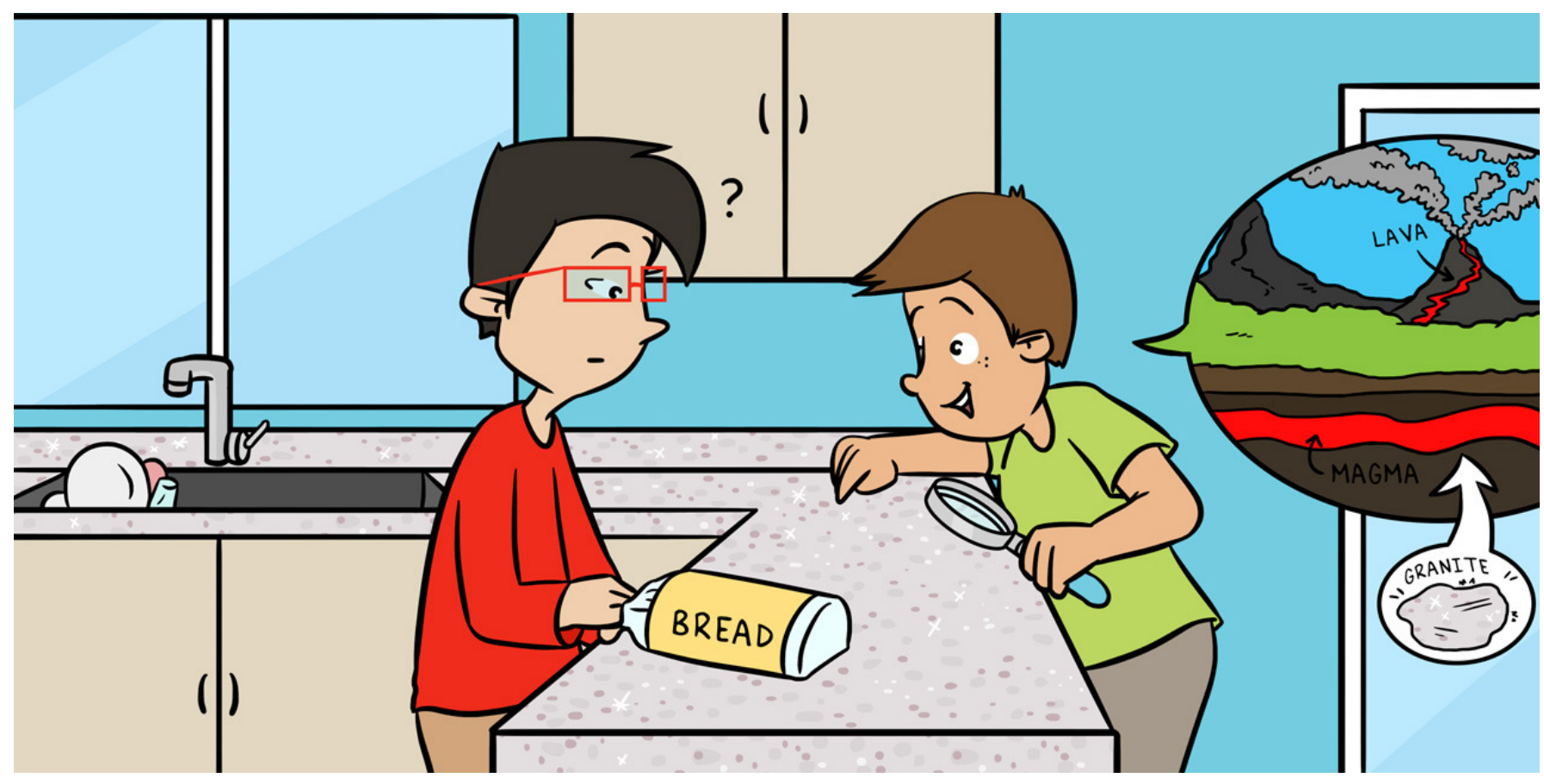

\title{
THE LIFE OF VOLCANIC ROCKS DURING AND AFTER AN ERUPTION
}

Christina Brennan ${ }^{1}$, Vishnu Prithiv Bhathe ${ }^{1}$, Stephanie Ellis ${ }^{1}$, Emily Moynes $^{1}$, Brian Cousens ${ }^{2}$ and Sean J. Landsman ${ }^{1 *}$

${ }^{1}$ Institute of Environmental and Interdisciplinary Science, Carleton University, Ottawa, ON, Canada

${ }^{2}$ Department of Earth Sciences, Carleton University, Ottawa, ON, Canada

YOUNG REVIEWER:

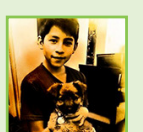

ALEJANDRO

AGE: 12
Volcanoes are constantly growing and changing. Every time a volcanic eruption occurs, new rock is added to the surrounding area. These eruptions play a big part in the formation and destruction of rocks as well as in shaping the Earth's surface. Yet, we do not know everything about the histories of the volcanoes that previously existed on Earth. Volcanologists-scientists that study volcanoes-can study the types of rocks that volcanoes produce, to gain a better understanding of volcanoes. These rocks vary based on the characteristics of the volcano from which they came. Volcanic rocks are unique because we can study them to accurately discover when and how they were formed. In this article, we explain the processes that make volcanic rocks and formations look different from each other. We also discuss ways that volcanologists can determine how ancient volcanoes were made, by studying the rocks produced during past eruptions. 


\section{LAVA}

Molten rock that has erupted at the Earth's surface.

\section{MAGMA}

Molten rock below or within the Earth's crust.

1 To read about volcano personalities, check out this article: Available online at: https://kids.frontiersin. org/article/10.3389/ frym.2018.00010/.

2 To read more about the different types of volcanoes, see this webpage: Available online at: https:// openpress.usask.ca/ physicalgeology/ /11-3-types-ofvolcanoes/.

\section{VOLCANOES AND IGNEOUS ROCKS}

While geologists are scientists who study all kinds of rock, volcanologists are geologists who focus on past and present volcanoes, lava, and magma. Volcanologists also study the rocks that volcanoes make, looking for clues to help them figure out how and when the volcanoes were formed. By figuring out the conditions that created volcanic rocks, volcanologists can learn about the history of a volcano and possibly predict whether a volcano will erupt again-and what will happen to the landscape and the people living nearby if it does. The rocks surrounding volcanoes give us important data to calculate the volcano's age and to help us answer questions about how the Earth was formed, including when volcanoes erupted and how explosive the eruptions were [1].

The types of rocks that volcanologists spend their time studying are called igneous rocks. Igneous rocks form when molten rock cools and hardens into solid rock. Molten rock is called magma when it is stored in a chamber beneath a volcano, but it is referred to as lava when it reaches the surface. Volcanoes are created whenever there is a break in the Earth's crust that opens a pathway for magma and gas to escape. Every time a volcano erupts, it changes in shape and size because the lava it releases cools and hardens around it. With time, this can make the volcano higher and wider. The largest volcano in the solar system is called Tamu Massif, located east of Japan at the bottom of the Pacific Ocean. While its height is average, what makes this volcano so large is how far it spans outward. Tamu Massif spans over 553,000 square kilometers, making it larger than the entire country of Spain [2]!

Volcanoes are classified by their shapes and where magma is stored within them, which both determine how magma tends to be released during eruption. Some volcanic eruptions are violent, spewing molten rock and gases into the air, while other volcanic eruptions are less explosive but equally damaging, because lava flows out of the volcano and spreads over large distances. For example, shield volcanoes, like Tamu Massif, are the main type of volcanoes that make up the Hawaiian Islands. Shield volcanoes have very fluid lava but do not have violent eruptions. If lava meets water, however, the interaction can cause the eruptions to become extremely explosive [3]. The other three major volcano types are cinder cones, stratovolcanoes, and lava domes, all of which are much more explosive than shield volcanoes ${ }^{1}, 2$. The large differences in how volcanoes erupt affect the type of lava flows they produce.

\section{LAVA FLOWS}

Lava flows in different ways. Understanding flow types can help volcanologists categorize igneous rocks because features of the rocks change as they cool and harden. Even though lava acts like a liquid, 
Figure 1

Four types of lava flows. (a) Pahoehoe lava flow, which is slow moving, on a shield volcano. (b) A'a lava flow, which is fast moving, on a shield volcano. (c) Blocky lava flow, which is fast moving and high viscosity, on a stratovolcano. (d) Pillow lava flow on the ocean floor. All photos are Public Domain.

\section{VISCOSITY}

Runny or sticky consistency; resistance to flow.
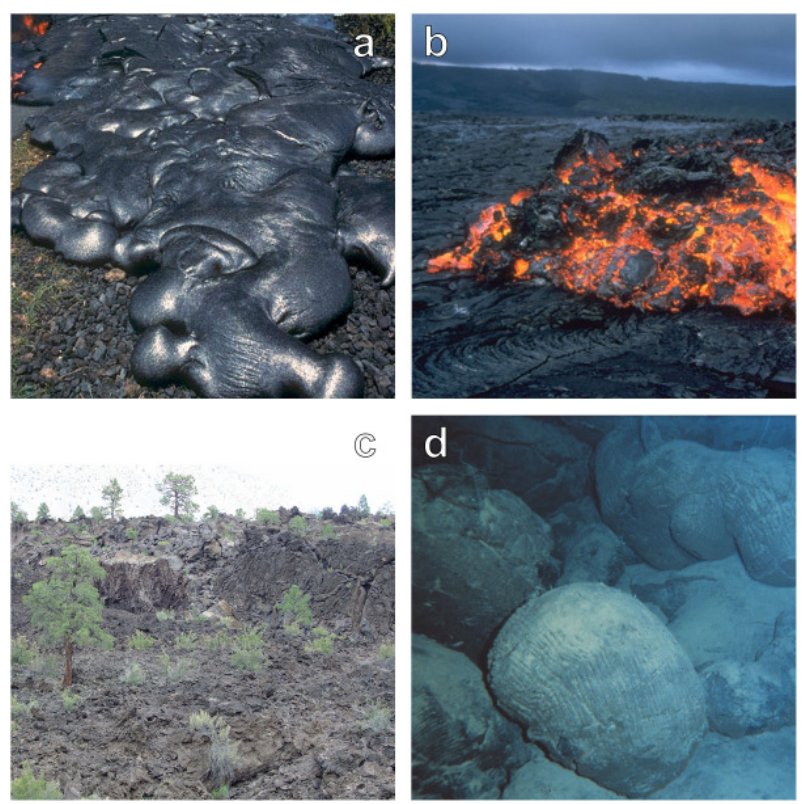

Figure 1

it is constantly cooling as it moves. This makes it behave differently depending on its composition and how quickly it is moving. The type of lava flow depends on the lava's viscosity, or resistance to flow.

The four main types of lava flows are pahoehoe, a'a (pronounced "ah-ah"), blocky, and pillow. Pahoehoe lava (Figure 1a) forms smooth continuous rock, because it is low viscosity and slow moving. A'a lava flows (Figure 1b) occur when lava flows quickly and crumbles at the top and the base, giving it a rubbly appearance. Blocky flows (Figure 1c) are like a'a flows but happen only with high viscosity lava. Instead of smooth rock formations, blocky flows break up and create angular boulders. Blocky flows can reach more than 100 meters in height, like a wave growing outward as it travels, before they topple over. Pillow lava (Figure 1d) only occurs underwater. As the hot lava flows into the cold water, the edge of the flow quickly cools to form volcanic glass, but the inside of the flow continues to move and break through the glassy edge, forming a pillow shape.

Sometimes when lava flows on land, the outside layer of the flow cools and hardens first while the inside layer continues to flow, insulated by the outer rock layer. The result is the formation of a lava tube (Figure 2). Lava tubes usually only form when the lava is low viscosity and fast moving. As the lava supply to the tube runs out, the tube empties and the hardened outside tunnel remains, leaving behind a long cave stretching from the base of the volcano, with smooth, flat floors like a hallway where the last of the lava flow hardened [4].

Studying lava flows is interesting because it allows volcanologists to see how a landscape can be formed or dramatically changed because 
Figure 2

A lava tube found in Valentine Cave, Lava Beds National Monument, California, USA. [Photo credit: Dave Bunnell/CC BY-SA 2.5 , face of person in the photo blurred to protect privacy].

\section{LAVA DOMES}

A circular mound that results from the slow eruption of viscous lava that piles up around the vents of some volcanoes.

\section{CRYSTALLIZATION}

A process where molten (liquid or semi-liquid) rock hardens into solid rock.

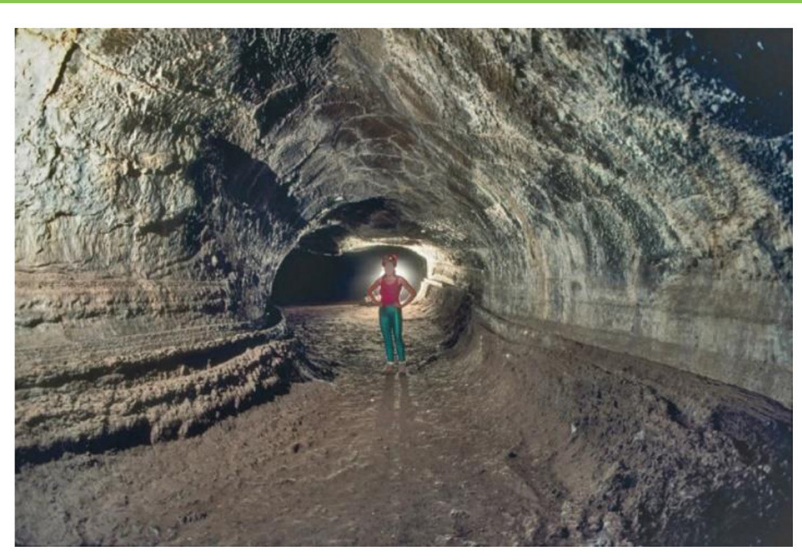

Figure 2

of volcanic activity. Underwater volcanoes play an important role in the formation of the ocean floor and new volcanic islands, while volcanoes on land are constantly forming and re-shaping the land around them.

\section{CRYSTALLIZATION OF LAVA}

Before magma leaves a volcano, it exists in one of three major forms, based on their chemical composition, viscosity, and temperature. They are all extremely hot and too dangerous to measure up close, so they are measured with thermal cameras instead [5]! The different types of magma determine what the cooled, solidified rock will look like. Some magma is very fluid and forms pahoehoe or a'a lava flows, which travel long distances. Other magma is more viscous and cooler, forming blocky lava flows. Magma can also be highly viscous, relatively cool, and form lava domes or blocky lava flows.

The type of magma, how long it takes to cool, and the gas present during a volcanic eruption impact what an igneous rock looks like after cooling and solidifying. Solidification of molten rock is called crystallization. Igneous rocks that cool underground cool more slowly, giving mineral crystals time to grow within the rock. In these rocks, the different minerals are large and easy to see with the naked eye. Igneous rocks that crystallize at the earth's surface tend to cool much more quickly and have much smaller crystals. A volcanic rock made entirely of glass, called obsidian, forms from lava that cools with little to no crystals at all. If lava is flung into the air during an eruption, or if it comes in contact with water, the edges of the lava will also cool to form a glass.

When volcanoes violently erupt, many gas bubbles form in the lava, so it crystallizes into rocks filled with holes where the gas used to be. Rocks with holes formed from gas trapped in the lava are called vesicular rocks. Gases can sometimes be trapped 
Figure 3

Examples of igneous rocks formed by volcanic eruptions. Felsic rocks are named for their high content of light-colored minerals; mafic rocks contain much darker minerals; intermediate rocks have a more balanced blend of darker and lighter minerals. [Photo credits: Granite-Eurico Zimbres/CC BY-SA 2.0; Pumice-Benjamint444/ CC BY-SA 3.0; Obsidian, Andesite-James St. John/CC BY 2.0:

Basalt-Jan Nyssen/CC BY-SA 4.0;

Scoria-Jonathan Zander/CC BY-SA 3.0 Background removed from all photos].

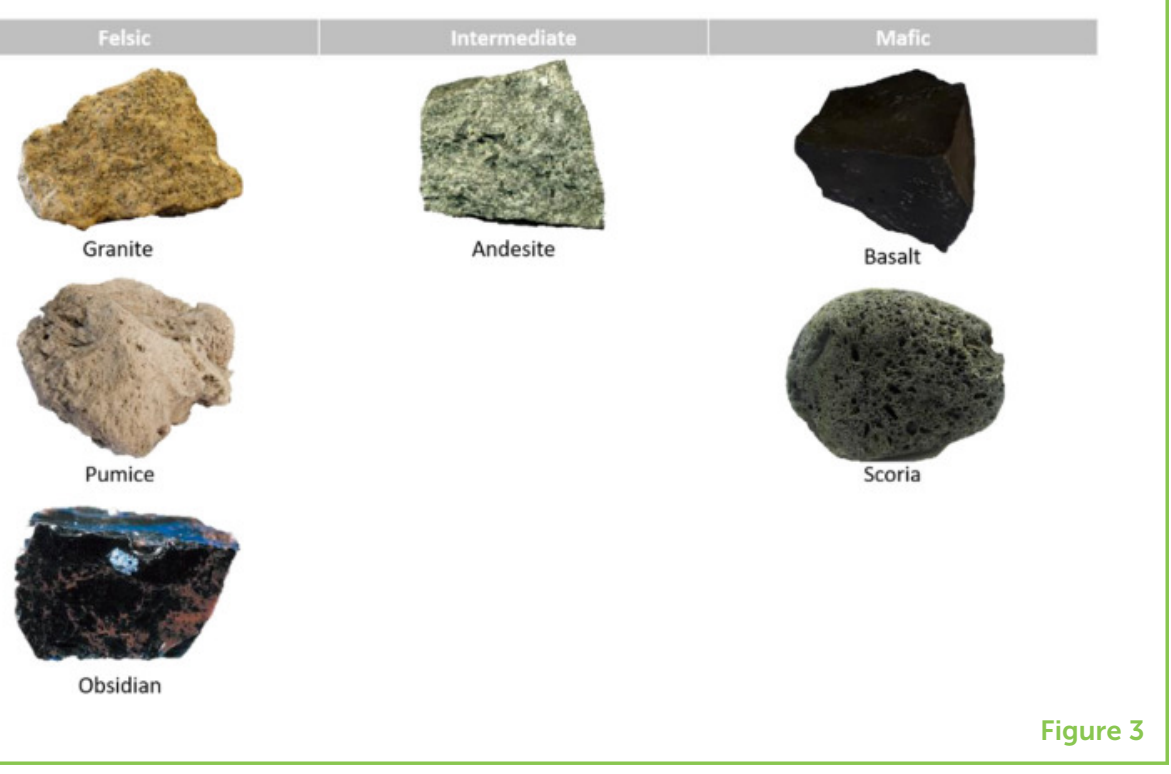

in the rocks, allowing volcanologists and geologists studying old vesicular rocks to determine which gases were present in ancient volcanoes [6]. Lava that contains very little gas tends to have no gas bubbles.

\section{TYPES OF IGNEOUS ROCKS}

Volcanologists have names for all the various kinds of rocks that are formed from volcanic eruptions. These rocks are first classified into categories, including felsic, mafic, and intermediate, based on the types of minerals they contain (Figure 3). Basalt is the most common type of igneous rock made from lava. Basalt is a dark-colored rock in the mafic category, with very little crystal formation. In contrast, andesite, an intermediate rock, is much lighter in color and has many crystals visible without a magnifying glass. Granite is a type of non-volcanic igneous rock, formed from magma cooling slowly underground. Granite is often used for kitchen or bathroom countertops and can be found in a variety of colors, all sharing similar crystal size and mineral compositions.

Rocks without obvious crystals also vary a lot in color and texture. Pumice is an example of a light-colored, felsic, vesicular rock that can float in water. Scoria is also vesicular but is dark, mafic, and denser, unable to float in water. Obsidian, composed of volcanic glass, is a felsic rock that cooled with no crystals. Although obsidian appears to be dark, like basalt, it is felsic in composition. Its dark appearance is due to impurities like iron or magnesium present within the rock. 


\section{WHAT CAN IGNEOUS ROCKS TEACH US?}

Many factors play a part in how rocks are created from volcanic eruptions, and what types and shapes of rocks volcanoes can produce. Volcanologists can look at igneous rocks that formed from a volcano to understand how it erupted, to study its geological history, and to predict future eruptions. Rock samples from multiple locations around a volcano can be dated to help construct an eruption history for the volcano. Using satellite imaging, geologic maps can be created to show how each of the volcanic materials are distributed. Using this information, as well as many other pieces of evidence, volcanologists can create a timeline of events for a volcanic region [7]. Not every site will have only one kind of igneous rock, and some sites may have had multiple volcanic eruptions, which makes this process extremely complex.

Using information from volcanoes to tell the story of earth's geological past is fascinating, because it may help us to answer some key questions. For example, did volcanic activity cause any of the known mass extinctions? If we can find a specific area of the world with many volcanoes that erupted around the time of a known mass extinction event, we could have evidence to support that the two are linked [8]. Volcanic eruptions spew large amounts of gases and ash into the atmosphere, and both can affect climate. In particular, volcanic gases such as sulfur dioxide can trigger global cooling, whereas carbon dioxide can contribute to global warming. The study of volcanic rocks is an interesting job, typically involving travel to locations of active and dormant volcanoes around the world for the collection of data and samples of rocks to examine later in a lab. Such a career offers a fascinating glimpse into the history of our planet!

\section{REFERENCES}

1. Kiyosugi, K., Connor, C., Sparks, R. S. J., Crosweller, H. S., Brown, S. K., Siebert, L., et al. 2015. How many explosive eruptions are missing from the geologic record? Analysis of the quaternary record of large magnitude explosive eruptions in Japan. J. Appl. Volcanol. 4:17. doi: 10.1186/s13617-015-0035-9

2. Zhang, J., Chen, J. 2017. Geophysical implications for the formation of the Tamu Massif - the Earth's largest single volcano - within the Shatsky Rise in the northwest Pacific Ocean. Sci. Bull. 62:69-80. doi: 10.1016/j.scib.2016.11.003

3. Wohletz, K., Heiken, G. 1992. Volcanology and Geothermal Energy. Berkeley: University of California Press. p. 26-39. Available online at: http://ark.cdlib. org/ark:/13030/ft6v19p151/

4. Piombo, A., Di Bari, M., Tallarico, A., Dragoni, M. 2016. Thermal anomaly at the Earth's surface associated with a lava tube. J. Volcanol. Geotherm. Res. 325:148-55. doi: 10.1016/j.jvolgeores.2016.06.019

5. Patrick, M. R., Orr, T., Antolik, L., Lee, L., Kamibayashi, K. 2014. Continuous monitoring of Hawaiian volcanoes with thermal cameras. J. Appl. Volcanol. 3:1. doi: 10.1186/2191-5040-3-1 
6. Xinhua, M., Guohui, L., Danlin, Y., Benjian, Z., Ya, L., Xin, D., et al. 2019 Distribution and gas-bearing properties of Permian igneous rocks in Sichuan Basin, SW China. Pet. Explor. Dev. 46:228-37. doi: 10.1016/S1876-3804(19) 60004-2

7. Guilbaud, M., Siebe, C., Layer, P., Salinas, S. 2012. Reconstruction of the volcanic history of the Tacámbaro-Puruarán area (Michoacán, México) reveals high frequency of Holocene monogenetic eruptions. Bull. Volcanol. 74:1187-211. doi: 10.1007/s00445-012-0594-0

8. Davies JHFL, Marzoli, A., Bertrand, H., Youbi, N., Ernesto, M., Schaltegger, U. 2017. End-Triassic mass extinction started by intrusive CAMP activity. Nat. Commun. 8:15596. doi: 10.1038/ncomms15596

SUBMITTED: 22 June 2020; ACCEPTED: 28 June 2021;

PUBLISHED ONLINE: 18 August 2021.

EDITED BY: Noemie Ott, Swiss Federal Laboratories for Materials Science and Technology, Switzerland

CITATION: Brennan C, Bhathe VP, Ellis S, Moynes E, Cousens B and Landsman SJ (2021) The Life of Volcanic Rocks During and After an Eruption. Front. Young Minds 9:575178. doi: 10.3389/frym.2021.575178

CONFLICT OF INTEREST: The authors declare that the research was conducted in the absence of any commercial or financial relationships that could be construed as a potential conflict of interest.

COPYRIGHT @ 2021 Brennan, Bhathe, Ellis, Moynes, Cousens and Landsman. This is an open-access article distributed under the terms of the Creative Commons Attribution License (CC BY). The use, distribution or reproduction in other forums is permitted, provided the original author(s) and the copyright owner(s) are credited and that the original publication in this journal is cited, in accordance with accepted academic practice. No use, distribution or reproduction is permitted which does not comply with these terms.

\section{YOUNG REVIEWER}

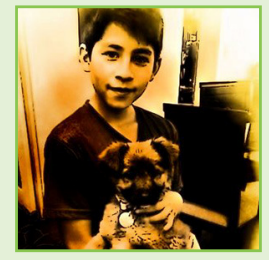

\section{ALEJANDRO, AGE: 12}

$\mathrm{Hi}$, my name is Alejandro. I am 12 years old and I live in Ecuador. I like rock music, sports, and animals. I also like trekking. My hobbies are play soccer, do exercise, read, and listen music. I like science because you can discover new things.

\section{AUTHORS}

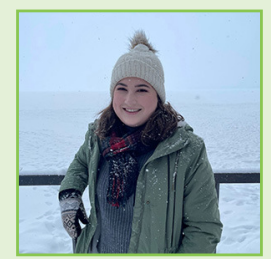

\section{CHRISTINA BRENNAN}

Christina Brennan is an undergraduate student at Carleton University in Ottawa, Ontario, Canada majoring in interdisciplinary science. She is especially interested in pursuing a career in science communication, and using the skills developed in her undergrad to bridge the gap between disciplines. Since she was 10 years old, 

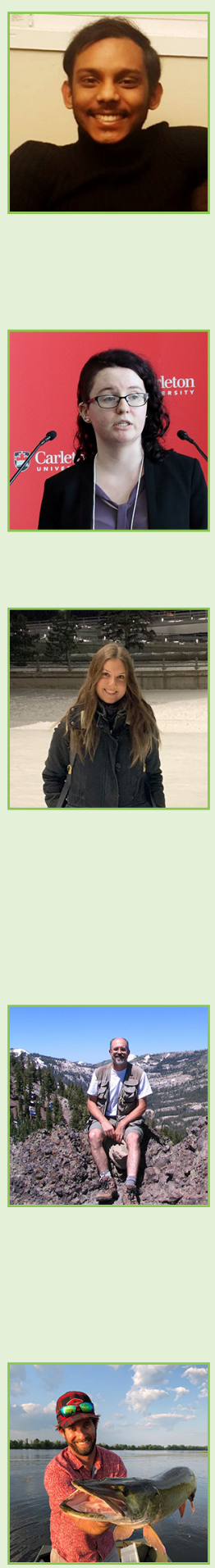

Christina has been designing floor plans of houses on graph paper and continues to do so today through 3D modeling. Aside from her academic goals, she hopes to 1 day design and build her own net zero home.

\section{VISHNU PRITHIV BHATHE}

Vishnu Prithiv Bhathe recently graduated from Carleton University in Ottawa, Ontario, Canada with a Bachelor of Science degree. Ever since he was a child, he has been curious about science and how people use the lessons from science to better the world. He is also interested in entrepreneurship and aims to use scientific research to fuel innovation. In his free time, he likes to ride bikes, paint, read books, and exploring new things.

\section{STEPHANIE ELLIS}

Stephanie is an undergraduate student in her final year of the Interdisciplinary Science and Practice program in Ottawa, Ontario, Canada. She is passionate about community engagement and figuring out how different systems work, from the human brain to computers. She was inspired by her teachers to continue searching for answers and to follow her passions at a young age.

\section{EMILY MOYNES}

Emily is a fifth-year undergraduate student studying Environmental Science at Carleton University in Ottawa, Ontario, Canada. During her schooling, she completed an internship under the supervision of Dr. Steven Cooke on various fish-related projects, resulting in a publication in Transactions of the American Fisheries Society. She is currently completing her honors thesis with Dr. Thomas Sherratt on insect body toughness. She loves acquiring new knowledge and experiences in her field and hopes to 1 day obtain a job exploring animal behavior or working toward conservation-related initiatives.

\section{BRIAN COUSENS}

Brian grew up in Montreal where he stumbled across the fantastic world of earth sciences at college and McGill University in Montreal, Quebec, Canada. His interest in volcanoes grew from studies of seafloor volcanism while at UBC in Vancouver and then ocean island volcanoes at UC Santa Barbara. Brian is a Professor in the Department of Earth Sciences at Carleton University in Ottawa, Ontario, Canada, specializing in the geochemistry of igneous rocks. He teaches field courses in volcanic regions such as eastern California, Nevada, Hawaii and Iceland.

\section{SEAN J. LANDSMAN}

Sean is a teaching professor in the Interdisciplinary Science and Practice program at Carleton University in Ottawa, Ontario, Canada on the unceded territory of the Algonquin First Nation. He is a trained fisheries ecologist and studies how fish move about their environments as well as how people affect them. He is also a passionate science communicator and enjoys sharing his knowledge with anyone that will listen! In fact, it was this love of communicating fisheries science that led him to photography and specifically underwater photography. Sean loves to spend time outdoors, especially fishing and hiking, and enjoys tinkering in his basement making things out of wood. *sean.landsmanecarleton.ca 